\title{
The Twilight of Mankind: Global Warming Cannot Be Managed through the COP21
}

\author{
Jan-Erik Lane \\ Public Policy Institute, Belgrade, Serbia \\ Email: janeklane@gmail.com
}

How to cite this paper: Lane, J.-E. (2017) The Twilight of Mankind: Global Warming Cannot Be Managed through the COP21. Open Access Library Journal, 4: e3311. http://dx.doi.org/10.4236/oalib.1103311

Received: December 16, 2016

Accepted: January 16, 2017

Published: January 20, 2017

Copyright $\odot 2017$ by author and Open Access Library Inc.

This work is licensed under the Creative Commons Attribution International License (CC BY 4.0).

http://creativecommons.org/licenses/by/4.0/

\section{(c) (i) Open Access}

\begin{abstract}
As the process of global warming pushes ahead, the UNFCCC keeps holding its large scale reunions, producing declarations only. Economists call these meetings transaction costs, because most of the $\mathrm{CO}_{2}$ emissions are produced by a small set of huge countries that could take speedy counter-action, if they wanted so. However, the COP21 Agreement about decarbonisation in this century is far too optimistic and does not confront the major obstacles in state coordination and international governance. One may devise utopian solutions to the global warming problematic, which is basically an energy problem, speaking of sustainable development. But realities are different, as the countries of the world cannot afford refraining from the fossil fuels. Energy innovations are available, but only on a small scale. Global warming results from the gigantic employment of energy resources, i.e. fossil fuels and wood coal. They are deemed necessary for economic and social development. The management tasks behind the COP21 project are simply too daunting, both nationally and internationally.
\end{abstract}

\section{Subject Areas}

Environmental Sciences, Political Economy

\section{Keywords}

COP21 Objectives: Goal I, Goal II and Goal III, GHG:s, $\mathrm{CO}_{2}$ :s and Methane, Positive Feedback, Logic of Government Coordination

\section{Introduction}

As we enter 2017, the overall situation with regard to global warming and the global environment is more and more worrisome [1]. On the one hand, the temperature rise continues, and in some areas quickly like the Poles and the oceans. The standard measure of $\mathrm{CO}_{2}$ on Earth keeps increasing, despite the fact 
that some countries now have declining $\mathrm{CO}_{2}$ curves. On the other hand, the evidence of grave environmental damages comes in, concerning plastics in the oceans, the death of barrier reefs, heavy periods of smog, more endangered species and huge regions of overfishing. This has been coupled to global warming. Something needs to be done, but is the COP21 Agreement really enough?

The COP21 Treaty promises most ambitious goals for the 21st century, but it lacks the means to achieve these goals. Thus, there will be an implementation deficit in the entire COP21 project. The objectives are as follows:

- Goal I: halt the increasing curve for country $\mathrm{CO}_{2}$ :s by 2020;

- Goal II: reduce $\mathrm{CO}_{2}$ :s by some 40 per cent until 2030;

- Goal III: accomplish more or less total decarbonisation until 2075.

One cannot overstate how bold these objectives are, given the information below about how much energy many countries use yearly. Obviously, the UNFCCC and country governments hope much of the blessings of modern non-renewable energy sources like solar, wind and geo-thermal energy besides atomic power. Two questions about feasibility may be posed:

- Can the big polluting Third World countries fulfill these goals, given their ambition to continue strong socio-economic development, the "catch-up" strategy [2] [3] [4]?

- Will the promised support from the First World be forthcoming in a way that secures efficiency and goal achievement-the Super Fund, as outlined by Stern already in 2007 [5]?

Big polluting countries do not want to cut back on economic development in order to decarbonize, but they cannot afford the required investments in energy transformation themselves. The promised Super Fund is gigantic-100 billion dollars per year for a decade, but Western governments are heavily indebted.

COP21 outlines decentralized decarbonisation. The responsibility for implementing the goals I-III rests exclusively with the national governments, as the oversight by the UNFCCC is to be minimal. It makes up a set of unbalanced arrangements to have an international organization allocate some 100 billion dollars per year while having virtually no control over the process-the Stern (2007, 2016) Super Fund. The likelihood that the sum of money is forthcoming in this uncontrolled manner is small, indeed.

\section{The Basic Link: Energy}

What makes the global warming problematic so intractable is the link between greenhouse gases (GHG) or $\mathrm{CO}_{2}$ :s and energy for mankind, which consists of almost 90 per cent of the burning of fossil fuels: coal, oil and natural gas besides wood coal. Since energy is indestructible, the burning of so much potential energy hidden in the soil and in forests releases heat of large proportions and GHG:s. The GHG:s, $\mathrm{CO}_{2}$ :s and methane etc. form a shield in the atmosphere of Planet Earth that traps this heat plus some of the heat from Sun radiation. The outcome is a growing from of entropy that in the long run makes the Planet Earth inhabitable-too warm for many living species. 
Energy resources are necessary for economic affluence. Energy is the capacity to do work and without work no production of goods and services, i.e. no income or wealth. Energy in various forms enters all kinds of social systems, and they are vital to economic systems. Let me point at two telling figures, but first some numbers in Table 1.

Not only may all forms of energy be measured, but all these measures are translatable into each other-a major scientific achievement. One may employ some standard sources on energy consumption and what is immediately obvious is the huge numbers involved-see Table 1.

Examining Table 1, one understands the size of the task of decarbonisation. Complete decarbonisation would mean the elimination of the energy consumption of fossil fuels and traditional renewables. This is a herculean task, impossible simply. But the mix of energy usage will change during this century towards more of carbon neutral energy sources.

Now, total energy consumed causes the total emissions of GHG:s from anthropogenic sources, which is driving climate change. Figure 1 shows how global GDP has expanded considerably the last 25 years with an enormous increase in total $\mathrm{CO}_{2}: \mathrm{s}$.

The findings in Figure 1 show that total GHG:s or $\mathrm{CO}_{2}$ :s go with larger total GDP, i.e. GDP per person * population. To make the dilemma of energy versus emissions even worse, we show in Figure 2 that GDP increase with the augmentation of energy per capita. This makes the turn to a sustainable economy suggested by Sachs in 2015 [6] unlikely, as nations plan for much more energy in the coming decades.

Decarbonisation is the policy promise to undo these "dismal" links by making GDP and energy consumption rely upon carbon neutral energy resources, like modern renewables and atomic energy. Thus, the upward sloping curves must be reversed but still slope outward. Putting Figure 1 and Figure 2 together, we arrive at the characteristic energy-emissions conundrum. Besides the global conundrum-GDP requires energy, but energy leads to GHG:s-there is an energy-emission conundrum for each government that signed the COP21 Agreement, to be the object of an inquiry below.

Table 1. Energy consumption 2015 (million tonnes of oil equivalent).

\begin{tabular}{ccc}
\hline Fossil fuels & $11,306.4$ & 86.0 \\
Oil & 4331.3 & 32.9 \\
Natural Gas & 3135.2 & 23.8 \\
Coal & 3839.9 & 29.2 \\
Renewables & 1257.8 & 9.6 \\
Hydroelectric & 892.9 & 6.8 \\
Others & 364.9 & 2.8 \\
Nuclear power & 583.1 & 4.4 \\
Total & $13,147.3$ & 100.0 \\
\hline
\end{tabular}

Source: BP statistical review of world energy 2016. 


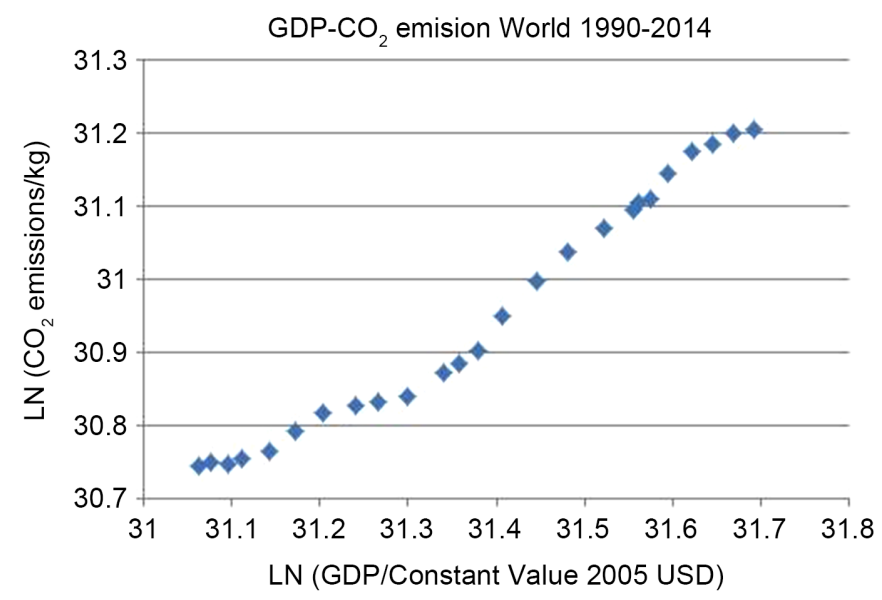

Figure 1. Global GDP- $\mathrm{CO}_{2}$ link: $\mathrm{y}=0.80 \mathrm{x}+5.96 ; \mathrm{R}^{2}=0.97(\mathrm{~N}=59)$.

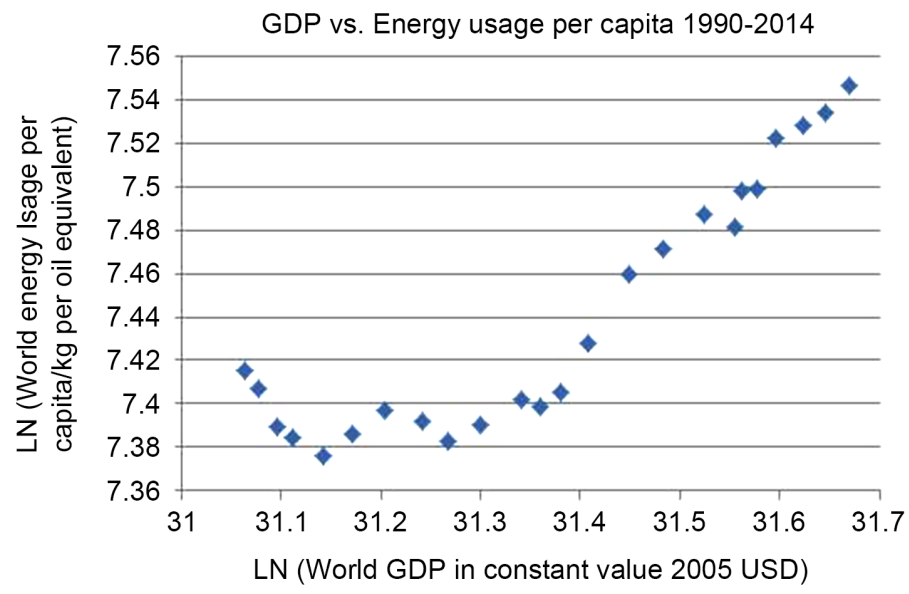

Figure 2. GDP and energy per person 1990-2014.

Figure 1 and Figure 2 identify the energy-emission conundrum that mankind faces this century with such dire consequences, including violent climate, droughts, sea level rise, ocean acidification, barrier reef death, water penury, famines, ecology refugees, etc. The theoretical underpinning of the empirical findings comes from the so-called Kaya model [7] (Appendix 1).

Economist J. Sachs argues that the energy-emission conundrum can be solved by moving to a model of sustainable economic development [8]. This is utopian.

\section{Rejection of "Sustainable Development"}

Insisting upon the positive nature of economics, "positive" referring to the understanding and prediction of the IS, one cannot but realize that sustainable development theory deals with the OUGHT. The gulf between normative utopia and harsh reality forces one to look for how adherents of sustainable economics get from realities to vision. Take the example of Sachs, stating about SDG (sustainable development goals) the following:

“... the SDGs need the identification of new critical pathways to sustainability. Moving to a low-carbon energy system, for example, will need an in- 
tricate global interplay of research and development, public investments in infrastructure (such as high-voltage direct current transmission grids for long-distance power transmission), private investments in renewable power generation, and new strategies for regulation and urban design. The task is phenomenally complex."

But Sachs does not inform us how something so "phenomenally complex" is to come about, going from the IS to the OUGHT. He continues:

"Market-based strategies (such as carbon taxation) can help to simplify the policy challenge by steering private decisions in the right direction, but politics, planning, and complex decision making by many stakeholders will be unavoidable." [9]

Of course, but what is the likelihood that a carbon tax can be put in place (where, how much) as well as how large is the probability that planning works? Only wishful thinking!

Sachs realizes the gap between desirability and feasibility, but he confronts the gap by almost religious make beliefs, saying:

"The SDGs will therefore need the unprecedented mobilisation of global knowledge operating across many sectors and regions. Governments, international institutions, private business, academia, and civil society will need to work together to identify the critical pathways to success, in ways that combine technical expertise and democratic representation. Global problem-solving networks for sustainable development-in energy, food, urbanisation, climate resilience, and other sectors-will therefore become crucial new institutions in the years ahead." [10]

What is at stake for most people who understand the risks with climate change is not the desirability of decarbonisation in some form or another. They crux of the matter is: How to promote decarbonisation so that real life outcomes come about?

One may come up with a wish list for how to save the Planet, but how likely is it that governments can or will embark upon them? The problem is the enormous size of energy transformation, the immense costs involved and the gaming strategies of the players involved. Proposals for a turn to huge solar and wind plants, for massive carbon sequestration, for huge carbon sucking schemes, for total elimination of coal, for the electrification of billion cars, for giving up cow meat, etc., are launched from time to time. But however important such innovations are, they cannot realistically solve the energy-emission conundrum. How is all the new demands for electricity to be supplied? Who pays for huge wind and solar plants? And what to do when the sun does not shine or the wind is calm?

Decarbonisation is decentralized policy-making and implementation. Let us examine the situation of a few key countries. Can they manage to fulfil the COP21 objectives? Is it probable, given their energy mix and energy-emission trend? 


\section{India: Coal-Stone or Wood-Cannot Be Replaced}

India is one of greatest polluters on the planet, and they are heading for the number 1 position, if the projection about population growth and economic development come true. The overall environment in South Asia is fragile by massive littering as well as recurrent droughts.

Energy consumption in India is planned to augment over the coming decade, as the ambition is to provide electricity to the whole population. Some 300 million people are today without electric power, and the population of India is growing fast. Mass poverty is the only outcome of this imbalance between total energy and total population, where India is heading for becoming the largest country in the world soon, population wise. Public intellectual and former minister Ramesh [11] states that India has no alternative but to build more coal fired energy plants. Thus, we may expect that Figure 3 will show more of an upward trend in the decade to come, violating already Goal I.

Besides burning lots of fossil fuels, Indian housholds rely much upon wood coal in its various forms, such as charcoal, peat and dung. Wood coal is detrimental to people and the environment. As wood coal releases $\mathrm{CO}_{2}: \mathrm{s}$, the use of biomass is typically defended by the argument that it also stores $\mathrm{CO}_{2}$, meaning that the use of biomass would be basically carbon neutral. However, this argument completely bypasses that wood coal in poor nations is conducive to deforestation and desertification, which is what happens on a large scale in India.

Figure 6 shows the constant increase in emissions. India will certainly appeal to the fairness problematic, namely per capita against aggregate emissions. India actually has one of the smallest numbers for energy per capita, although it produces much energy totally. The country is more negative than China to cut GHG emissions, as it is in an earlier stage of industrialization and urbanization, the "take-off" stage [12]. Figure 4 shows the close connection between carbon emissions and GDP for this giant nation.

India needs cheap energy for its industries, transportation and heating as well as electrification. From where will it come? India has water power and nuclear energy, but relies most upon coal, oil and gas as power source. It has strong

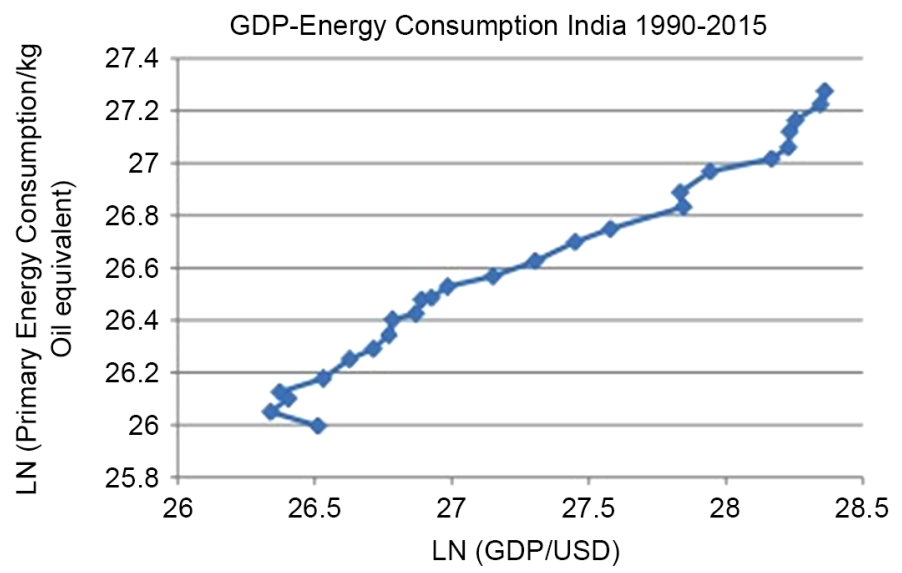

Figure 3. India's link GDP-energy: $y=0.55 x ; R^{2}=0.98$. 


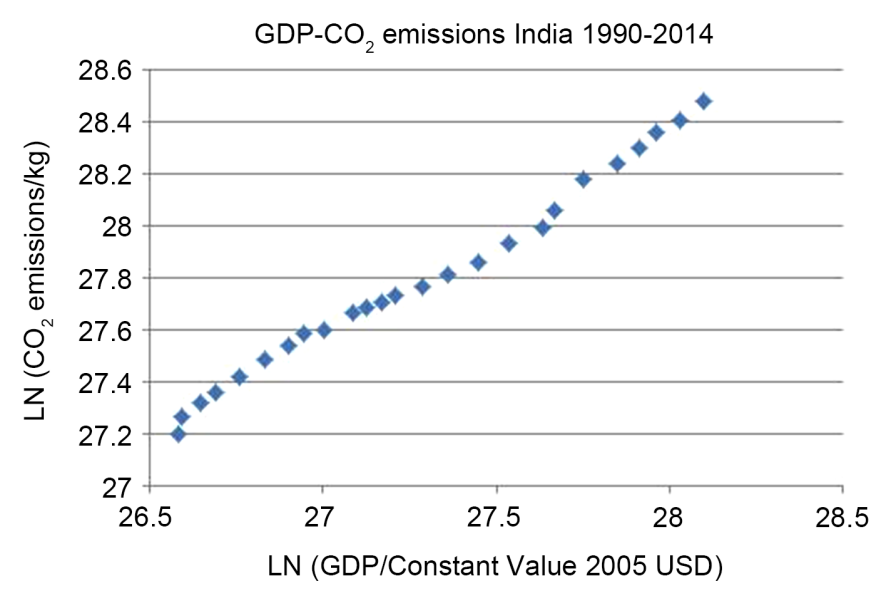

Figure 4. India: Link between GDP and $\mathrm{CO}_{2}: \mathrm{s}: \mathrm{y}=0.77 \mathrm{x}+6.79 ; \mathrm{R}^{2}=0.99$.

ambitions for the future expansion of energy, but how is it to be generated, the world asks. In its energy mix traditional renewables-wood, charcoal and dung-play a bigger role than in for instance China. Figure 5 shows its present energy mix.

India is heavily dependent upon stone and wood coal as well as oil and natural gas. To change this pattern towards modern renewables will take a long time and require massive financial assistance from the Super Fund. Since India is a federal state, the management tasks will be complex and involve conflicts between the powerful states. India cannot comply with the COP21 objectives. Energy transformation is slow and requires capital as well as policy-making. India's need for energy is overwhelming.

Global warming constitutes a major Negative for India, as water shortages limit hydro power and the melting of glaciers make water access unpredictable. In addition, the plains of India become too hot to do farming upon.

\section{China: Decarbonisation + Carbonisation = Little Change}

It holds true that China is taking several steps in the direction of decarbonisation, especially reducing the consumption of coal. Thus, atomic power stations are built and massive investments in solar and wind power occur. Yet, at the same time, China is pushing ahead with its socio-economic development towards modernisation and post-modernity, employing market incenyives [13]. New and bigger cars are sold, new autostradas are built, new airports are put up and urban developments are spawling with skyscrapers-all taking lots of cement. What does it add up to? Reply: need of energy.

In a uniquely rapid economic development over a few decades, China has moved from the Third World to the First World with stunningly new giant cities cropping up and modern infrastructure being introduced to its old cities. With economic growth rates hovering around 10 per cent, China is no longer a poor nation. The trick has been to employ market incentives, resorting to a massive mobilisation of energy, partly imported from Australia among others. Figure 6 has the colossal step forward towards a mature economy. 


\section{Energy Consumption in India}

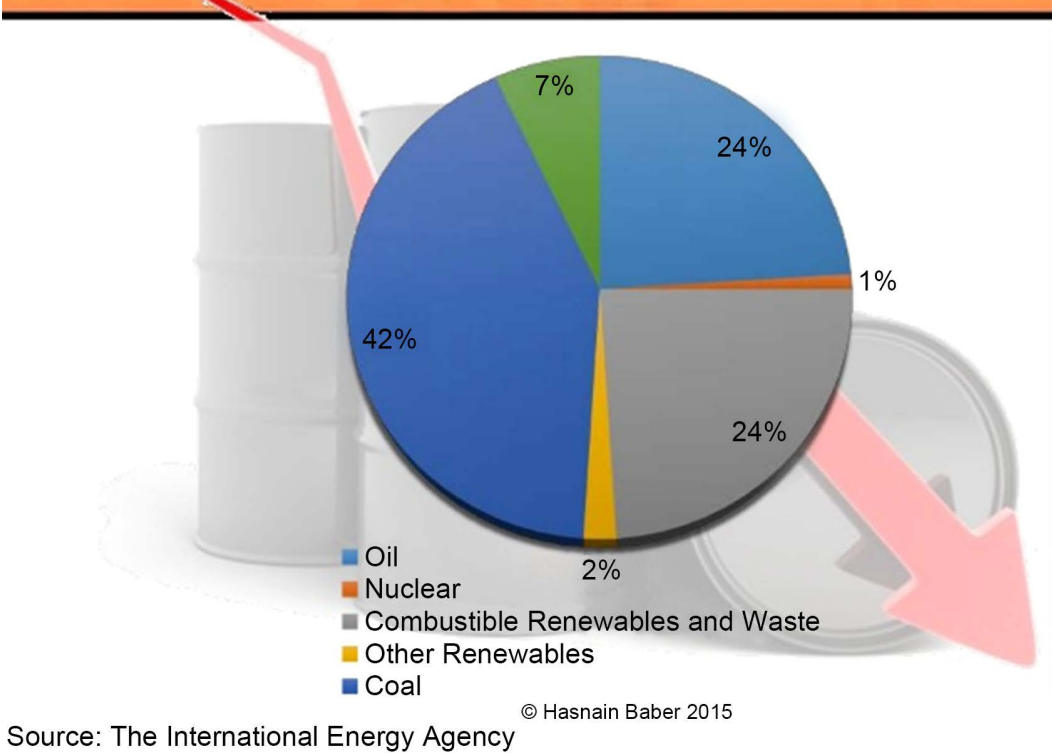

Figure 5. Energy mix in India 2014.

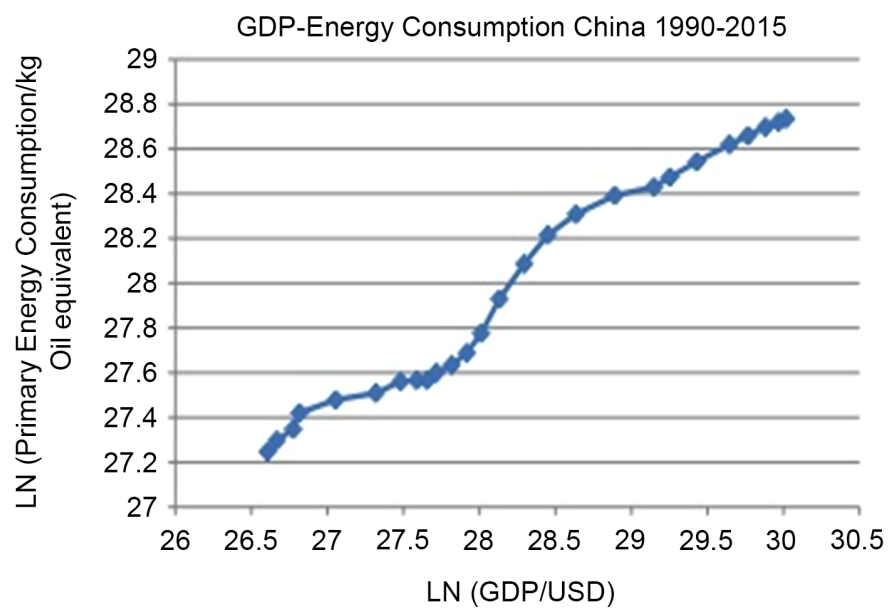

Figure 6. Energy and GDP in China: $y=0.46 x ; R^{2}=0.97$.

China has multiplied its energy usage several times over, drawing upon internal and external resources, mainly fossil fuels. It used to rely upon internal oil and natural gas, but now it is a major global importer. Its exports are gigantic to the US and the EU, and it is tying other Third World countries into patterns of cooperation, or some would say dominance economically, like African nations and Pakistan. However, the price is not only overall environmental deterioration but also the world's largest $\mathrm{CO}_{2}$ emissions (Figure 7).

A few nations do not depend upon any foreign assistance, because they are highly developed technologically and can draw upon own substantial financial resources. One may find that the emissions of GHG:s follows economic development closely in many countries. The basic explanation is population growth and GDP growth-more people and higher life style demands. Take the case of 


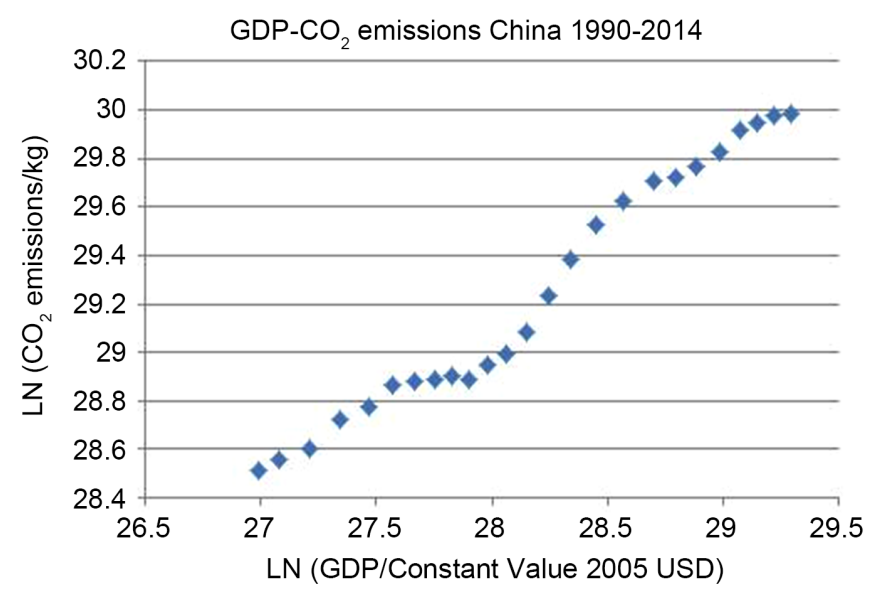

Figure 7. China: GDP- $\mathrm{CO}_{2}$ link: $\mathrm{y}=0.70 \mathrm{x} ; \mathrm{R}^{2}=0.97$.

China, whose $\mathrm{CO}_{2}$ emissions are the largest in the world, totally speaking. China was a Third World country up until yesterday.

The sharp increase in $\mathrm{CO}_{2}$ :s in China reflects not only the immensely rapid industrialization and urbanization of the last 30 years, but also its problematic energy mix with around 90 per cent of energy consumption coming from fossil fuels.

The energy consumption mix in China is different from that of India, as wood coal is not used much. Figure 8 has the energy mix.

It may be underlines that these data in Figure 8 underestimate the share of atomic and renewable power, but it provides an indication of how much China must change to comply with the COP21 goals. Water power is fully utilised, meaning that atomic, solar and wind power must be the future energy sources. In any case, China is not on route to achieve the COP21 goals.

\section{Indonesia: The Rain Forests Will Disappear}

Indonesia has rapidly moved up as a major consumer of energy in the early 21 rst decade, reflecting growth political stability and a strong effort to catch-up with the other Asian miracles. It has definitely passed its "take-off" stage, but interestingly its enormous consumption of energy has not been accompanied by high economic growth in most recent years (Figure 9).

The inward and upward sloping curve for Indonesia must be of concern to the elite in the country, because Indonesia has become a major contributor to $\mathrm{CO}_{2}$ emissions. If economic growth stalls due to inflation, then how to defend the enormous emissions?

The bad $\mathrm{CO}_{2}$ emissions stem partly from the cutting and burning of rain forests and adjacent land on Kalimantan and Sumatra, which the government is to weak to control. The illegal fires affect other neighbouring countries but little is done to stop them. The search for more land for agriculture, especially soya planations, drives the externality. Emissions even outpace energy consumption. These rain forests are bound to disappear, as the Indonesian state does not have the capacity or even willingness to police these huge areas. 


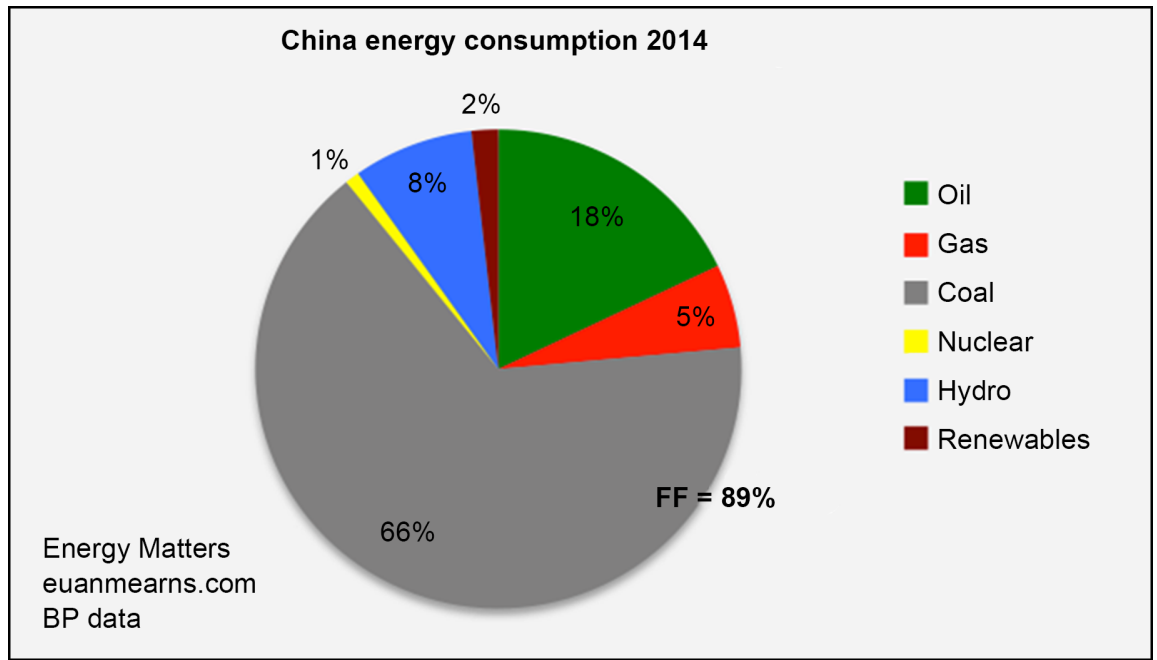

Figure 8. China's energy mix.

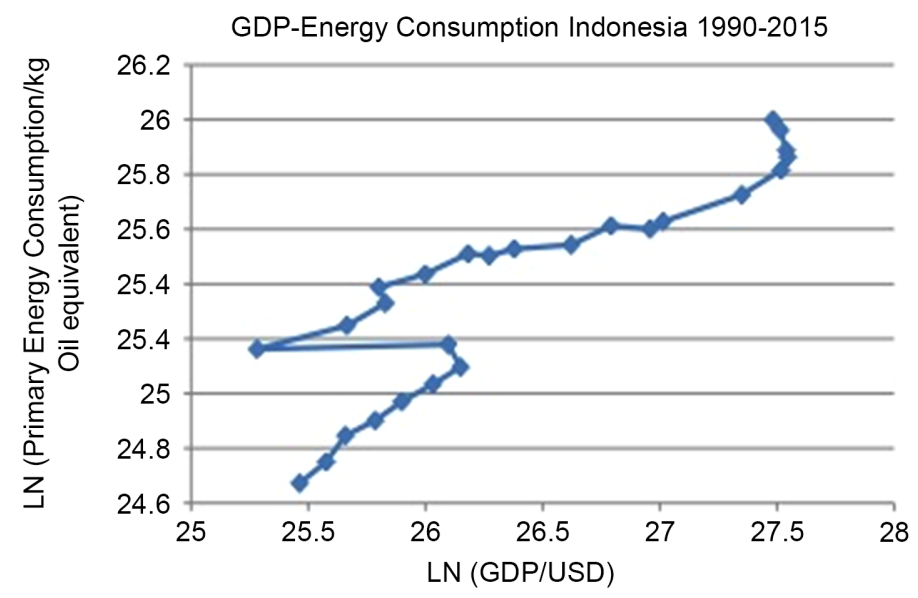

Figure 9. Indonesia: $y=0.46 x ; R^{2}=0.79$.

One may guess correctly that countries that try hard to "catch-up" will have increasing emissions. This was true of India. Let us look at three more examples, like e.g. giant Indonesia-now the fourth largest emitter of GHG:s in the world (Figure 10).

Indonesia is a coming giant, both economically and sadly in terms of pollution. Figure 10 reminds of the upward trend for China and India. However, matters are even worse for Indonesia, as the burning of the rain forest on Kalimantan and Sumatra augments the GHG emissions very much. Only 4 per cent comes from hydro power with 70 per cent from fossil fuels and the remaining 27 per cent from biomass, which alas also pollutes (Figure 11).

The reliance on fossil fuels and wood coal is too heavy in Indonesia in order to fulfil the COP21 objectives.

\section{South Korea: "Catch-Up" Trumps Everything}

A major industrial country in East Asia is South Korea with an advanced economy and large population. It deviates from the pattern of mature economies to 
display a slowing down in the $\mathrm{CO}_{2}$ :s (Figure 12).

Lacking much hydro power, South Korea has turned to fossil fuels for energy purposes, almost up to 90 per cent. Now, it builds nuclear plants, but South Korea needs to move aggressively into solar power to reverse trends. It differs from China only in the reliance upon nuclear power, where the country is a world leader in plant constructions. Reducing its GHG emissions, South Korea will have to rely much more upon modern renewable energy sources, as well as reducing coal and oil for imported gas or LNGs. Its appetite for energy is not slowing down (Figure 13).

South Korea is of course a mature economy, but it still pursues an aggressive catch-up strategy with strong claims in electronics and nuclear power technology besides shipping and car industry (Figure 14).

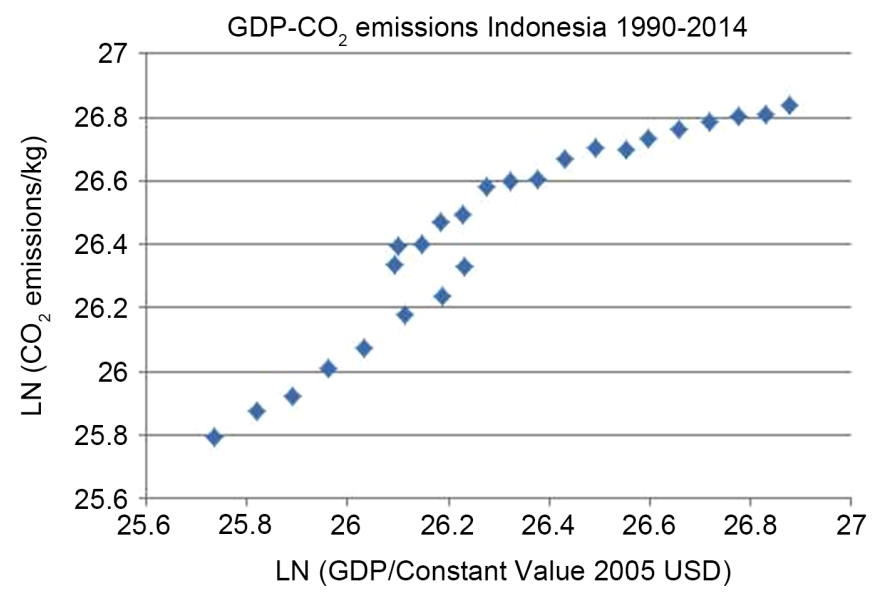

Figure 10. Indonesia: GDP- $\mathrm{CO}_{2}$ link: $\mathrm{y}=0.95 \mathrm{x}+1.58 ; \mathrm{R}^{2}=0.89$.

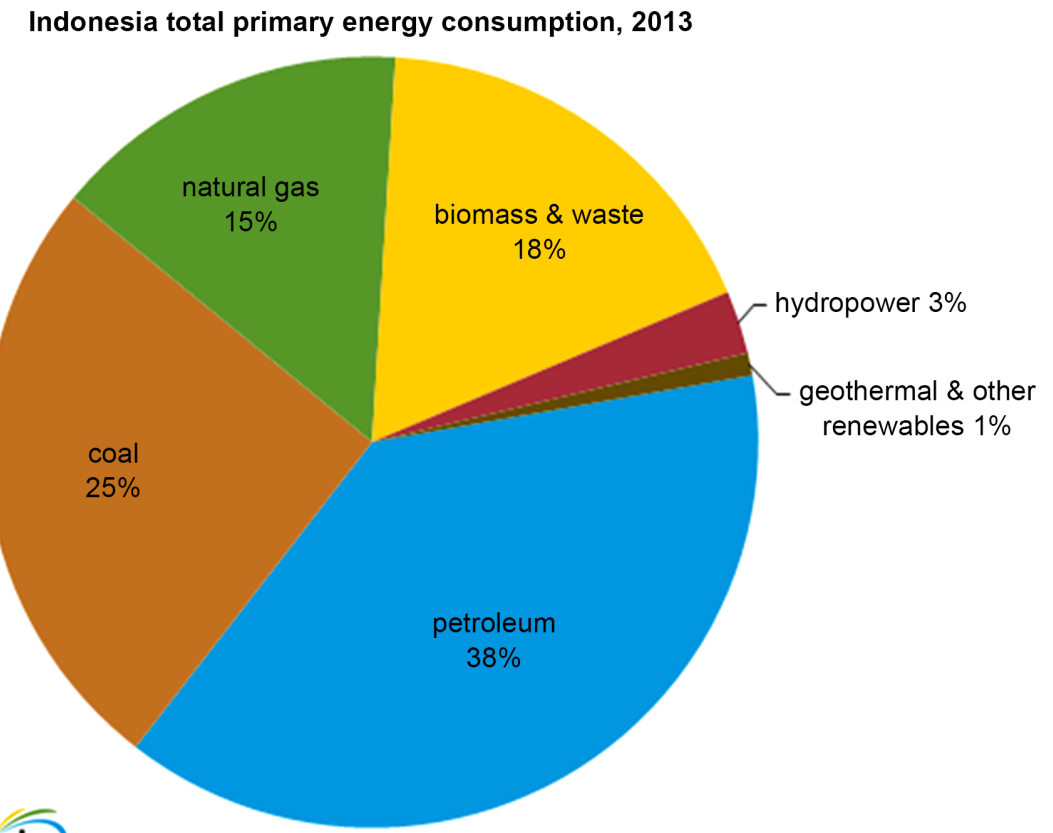

eia Source: Indonesia's Ministry of Energy and Mineral Resources

Figure 11. Indonesia's energy mix. 


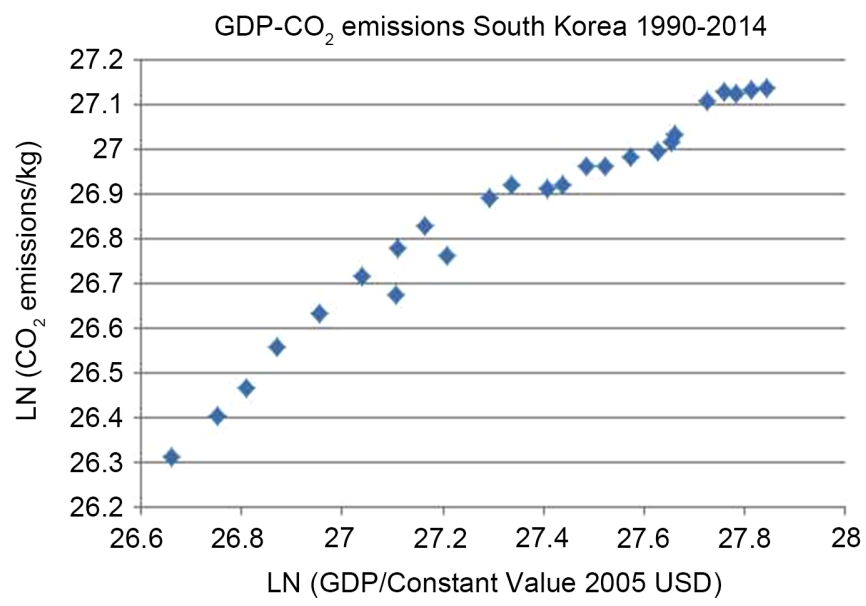

Figure 12. South Korea: GDP- $\mathrm{CO}_{2}$ link: $\mathrm{y}=0.65 \mathrm{x}+9.19 ; \mathrm{R}^{2}=0.96$.

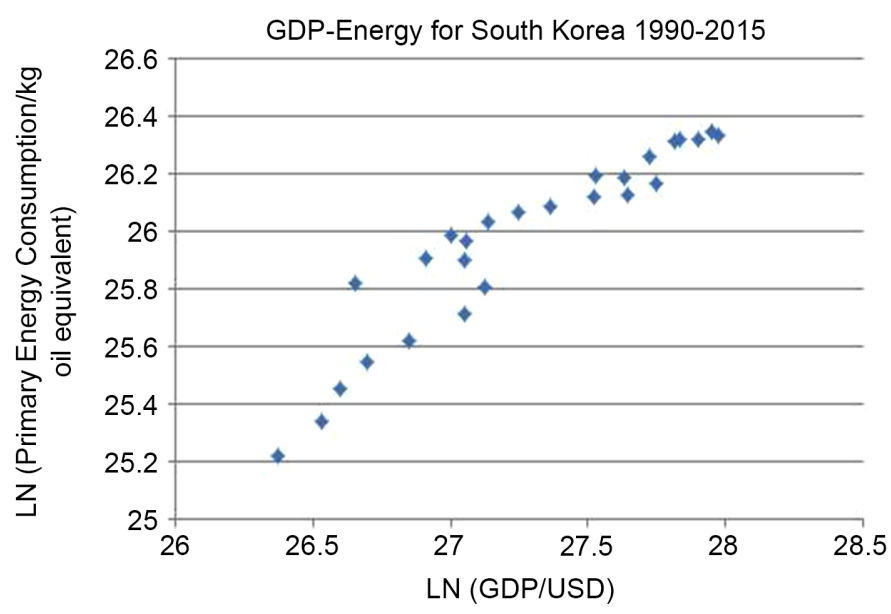

Figure 13. GDP-energy for South Korea: $y=0.622 x ; R^{2}=0.88$.

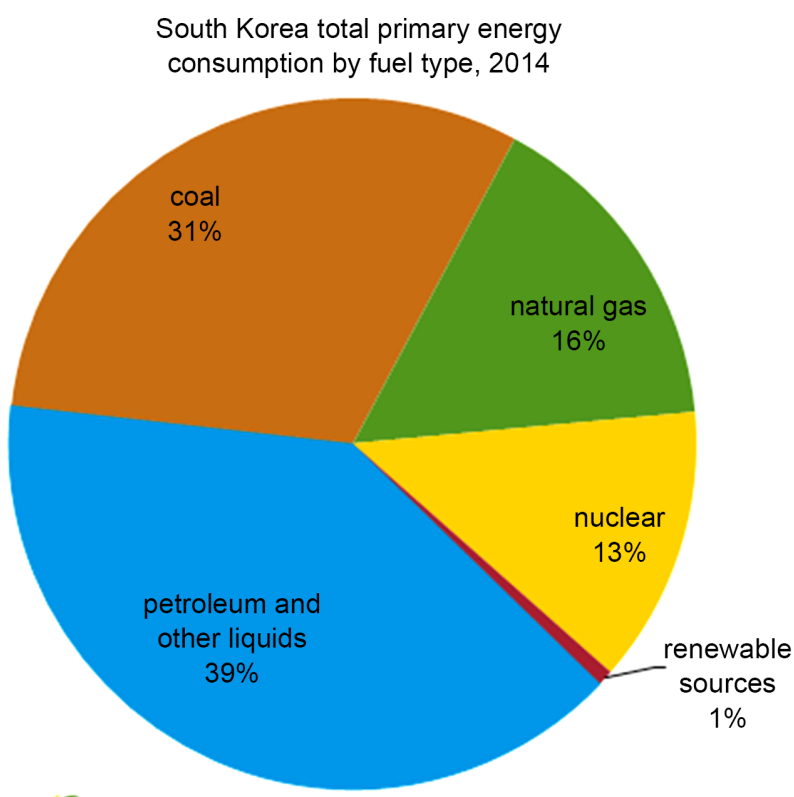

eia Source: BP Statistical Review of World Energy 2015

Figure 14. Energy mix in South Korea. 
South Korea is hardly on track for implementing decarbonisation, despite its impressive atomic program. Perhaps the availability of sun shine is not sufficient in South Korea for a major investment in solar plants, but in Saudi Arabia it is feasible.

\section{Saudi Arabia: Burning Oil Is Cheap}

In this country, almost all power comes from oil and natural gas. But the consumption of oil for electricity production has reached a level where solar power plants are interesting economically ("grid parity”). Thus, Saudi Arabia has big plans for renewable energy investments, especially solar power (Figure 15).

Yet, even if these plans for renewable energy come true in 2032, Saudi Arabia is still producing too much $\mathrm{CO}_{2}$ :s in order to fulfil the COP2 1 goal of 40 per cent reduction by 2030 .

The upward sloping curve for GDP and $\mathrm{CO}_{2}: \mathrm{s}$ is characteristic for the oil and natural gas producing countries. Some of them have already caught up, but remains committed to keep expanding their wealth, like giant Saudi Arabia (Figure 16).

Saudi Arabia consumes much energy to maintain its flamboyant life-style (Figure 17). It remain to be seen if the present economic difficulties of the country results in more of energy efficiency or a turn to renewables.

The drop in the oil price during 2016 has hurt Saudi Arabia badly, as it is now considering a new economic policy to maintain its affluence. Does it have enough resources for decarbonisation according to the COP21 scheme? As long as the oil price stays low, the incentives for decarbonisation must be weak. And the oil price now depends more on the US and Saudi Arabia.

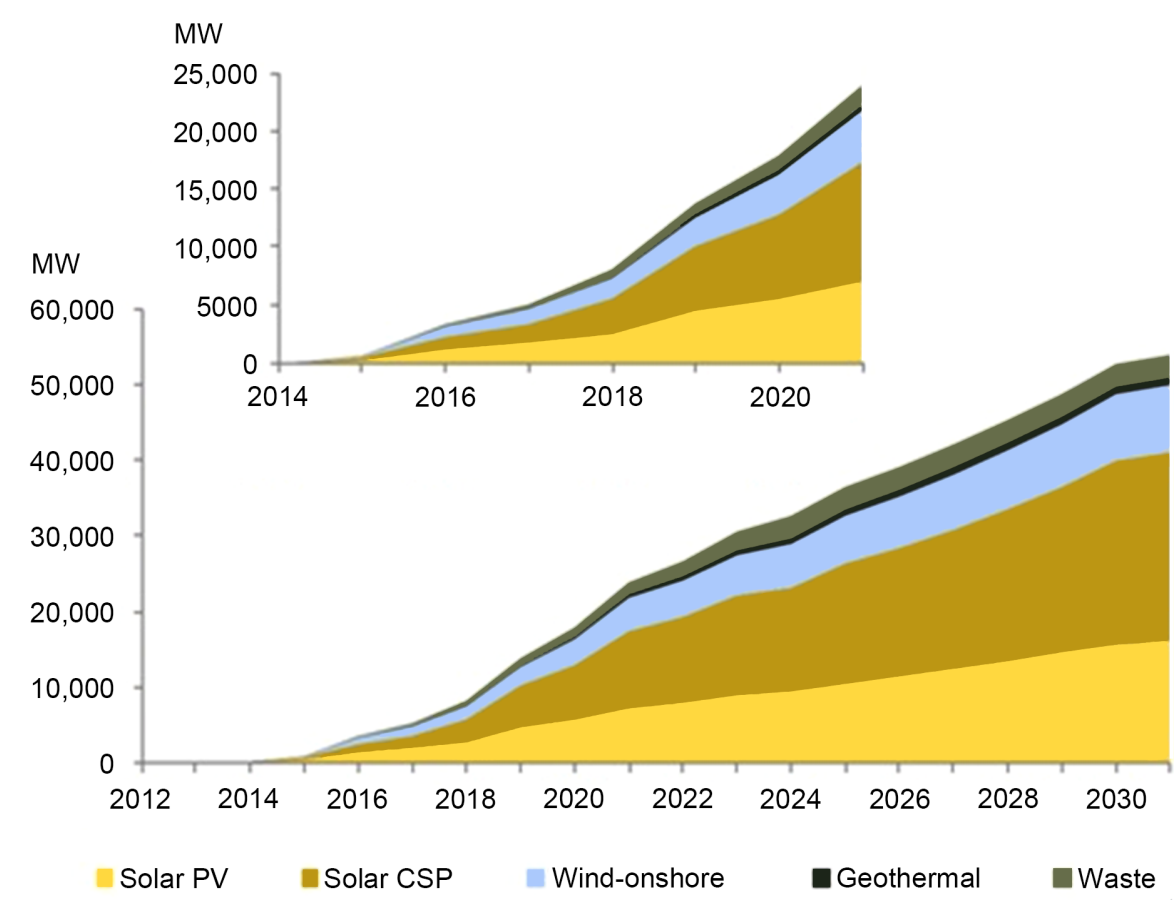

Figure 15. Plans for renewable power in Saudi Arabia. 


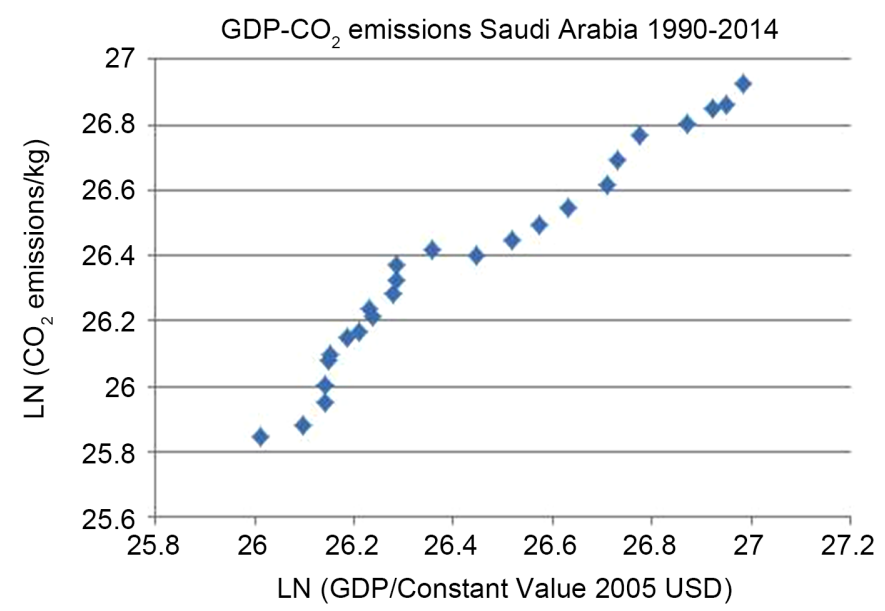

Figure 16. Saudia Arabia's GDP-emissions: $y=1.03 x-0.77 ; R^{2}=0.95$.

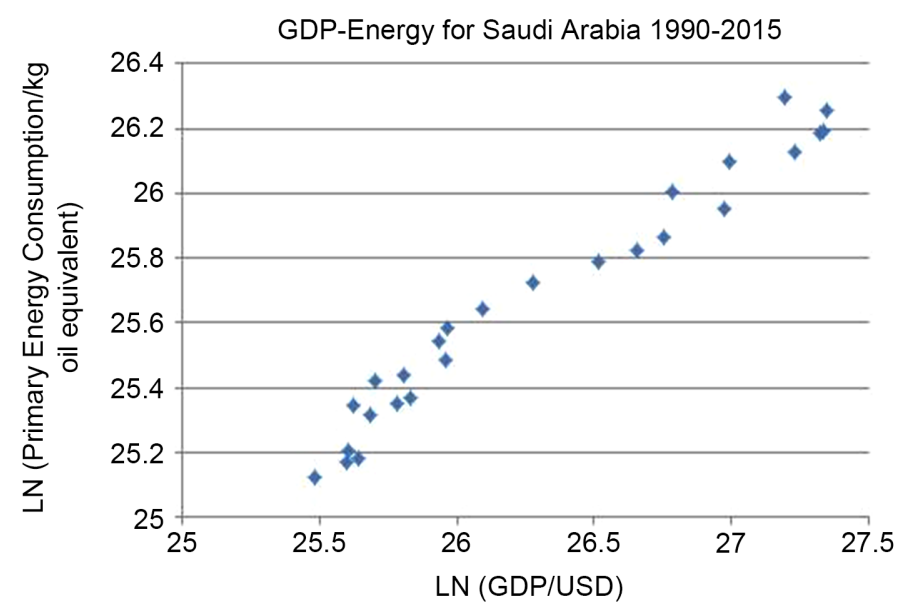

Figure 17. Energy-GDP in Saudi Arabia: $y=0.56 x ; R^{2}=0.96$.

\section{Brazil: The Amazons Will Be Savannah}

As the largest economy in South America with a swelling population, Brazil is in need of vast energy resources, as it hopes to "catch-up" with North America. But Brazil is extremely important for the energy-emissions conundrum not only because it produces lots of energy but also necause it harbours the lugns of Planer Earth. Barzil's emissions will include also the burning of the rain forest, the Amazons. The destruction of the Amazons has not been halted by the Brazilean state. On the contrary, it has recently picked up again.

Brazil may tap several domestic sources like oil and gas, ethanol and hydro power. The energy needs increase rapidly when there is positive economic growth (Figure 18).

Brazil employs the most biomass in the world-ethanol, but the emissions stay at a very high level, which is a reminder that even modern renewables may lead to $\mathrm{CO}_{2}$ :s. One advantage for Brazil is its large component of hydro power, but the overall picture for the largest Latin American country is not wholly promising, when it comes to reduction of emissions. Will it accomplish GOAL I-maybe! But hardly GOAL II. Two caveats: 
Global warming reduces the potential for hydro power-water scarcity, and Brazil has very little nuclear power. There are plans for no less than 30 hydro projects in the Amazon basin, but Brazil has first and foremost to come to terms with the extensive deforestation of this huge rain forest, contributing a lot to global warming. And other nations are involved here.

Biomass and waste only contribute to decarbonisation when there is a sequence of harvesting and build-up of new carbon consuming entities. When the rain forest is cut down once and for all, or poisonous waste burnt, then there is carbonization. Brazil pollutes a lot (Figure 19).

Brazil has increasing $\mathrm{CO}_{2}$ :s, which somehow must be reversed. It has a mix of energy sources, which should help fulfilling the COP21 goals (Figure 20). However, hydro power may dwindle due to droughts and whether ethanol produces $\mathrm{CO}_{2}: \mathrm{s}$ is much disputed. In any case, ethanol is clearly better than stone coal, like in South Africa, and wood coal, in Sub-Saharan Africa (Appendix 2).

I believe most "emerging economies" will rely much upon fossil fuels, like the

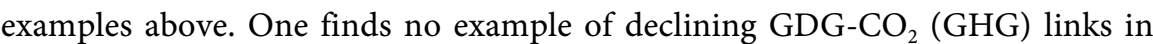
Latin American nations, nor in Africa or Asia, meaning that COP21 management will struggle to get GOAL I implemented. Again the Super Fund may be invoked.

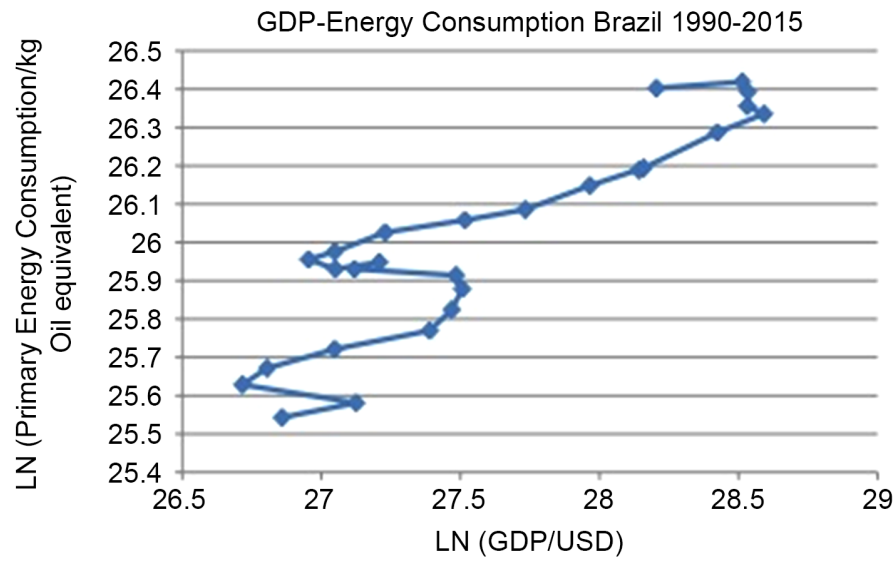

Figure 18. Brazil GDP-energy: $y=0.37 x ; R^{2}=0.81$.

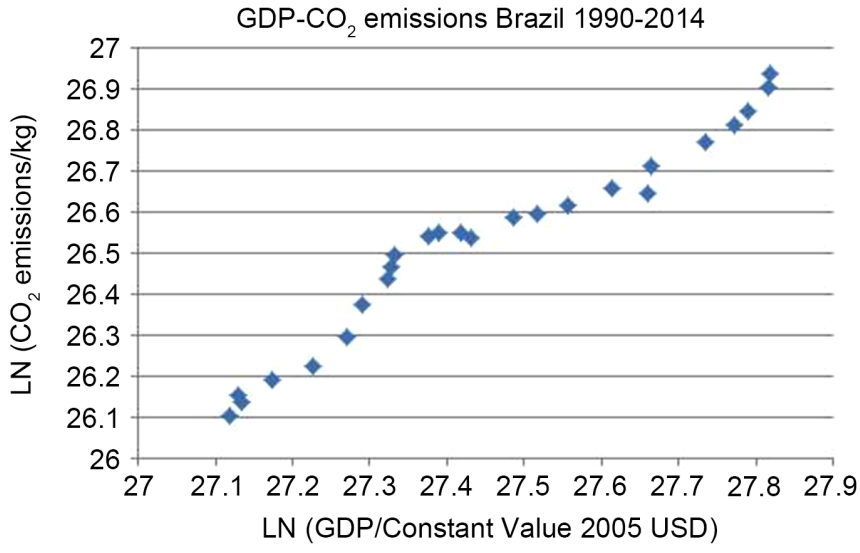

Figure 19. Brazil GDP-CO $\mathrm{CO}_{2}: \mathrm{y}=1.03 \mathrm{x}-1.7 ; \mathrm{R}^{2}=0.95$. 


\section{Brazilian Energy Matrix in 2014}

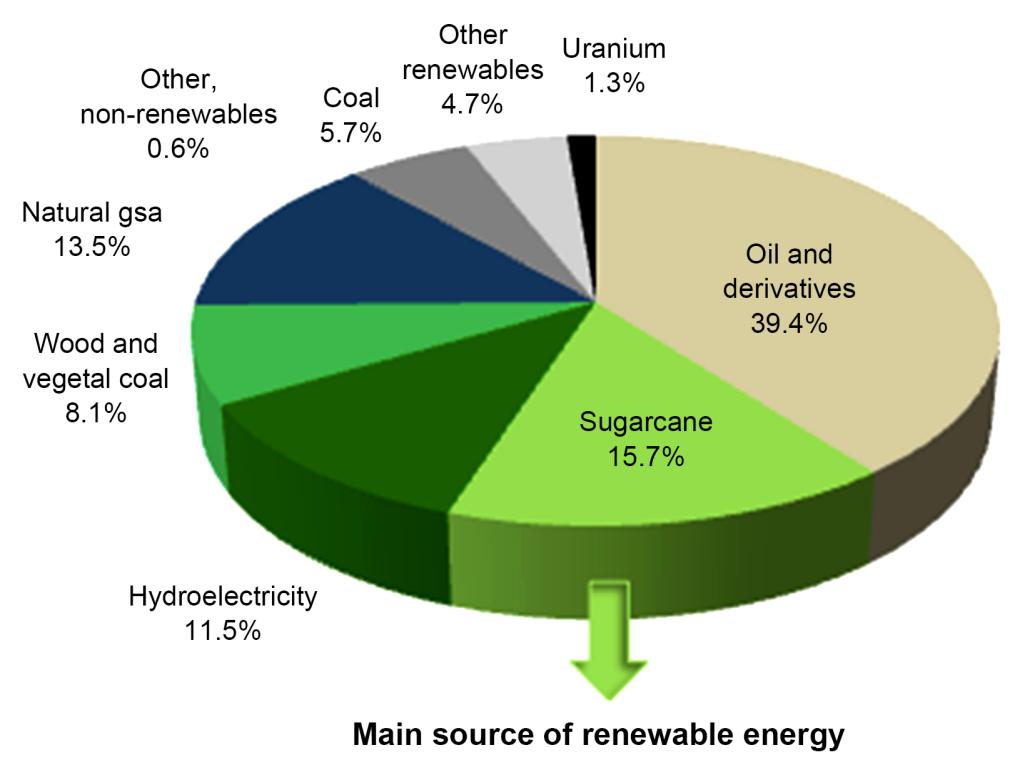

Source: Balanço Energético Brasileiro BEN (2015). Compiled by UNICA

Figure 20. Energy mix in Brazil.

\section{USA: Defection}

Energy consumption is almost as high in the US as in China, despite a much smaller population, meaning that per capita energy consumption is the highest in the world, outside of the Gulf States where Qatar is on top. Energy and affluence is basically the same, viz capacity to do work.

Figure 21 indicates that the upwards trend of energy use has recent stalled. This may be due to the financial recession starting in 2007-2008, but it may also be related to the ongoing energy transformation in the US, away from coal that delivered much of US energy consumption.

The plans of the EPA and EIA for future energy needs in the US include a heavy augmentation, but one cannot tell whether it will come about from renewables or fossil fuels like fracking. The market for energy is somewhat bewildering in the country with the start of oil and natural gas exports again as well as the shut down of a few atomic power plants. Yet, fracking is not environmental friendly. Lots of solar plants are coming up, but their efficiency is low compared with nuclear plants.

Figure 22 shows that carbon emissions have peaked for the US.

Recently, the level of $\mathrm{CO}_{2}$ emission has been reduced significantly in the US. It reflects partly the economic crisis that began 2007, but the entire energy pattern is undergoing change, from coal towards modern renewables. Yet, the US remains the second largest polluter in the world. This $\mathrm{CO}_{2}$ reduction reflects that the US can draw upon a mixed bag of energies, including nuclear and hydro power, with solar power expanding rapidly (Figure 23).

The US is still heavily dependent upon fossil fuels, as some 80 per cent comes there from, the US facing a challenge of reaching GOAL II. What is changing is 


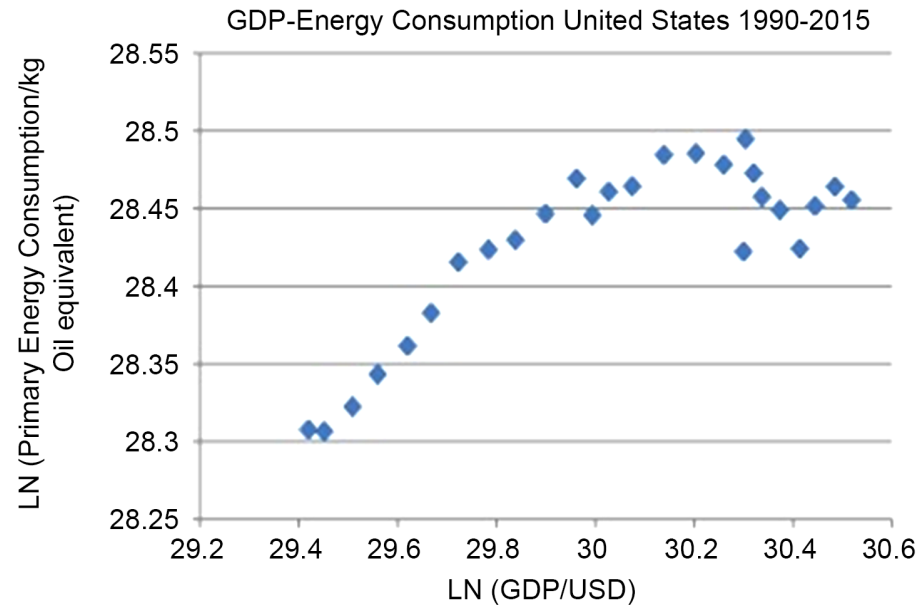

Figure 21. US:Energy and GDP: $y=0.46 x ; R^{2}=0.97$.

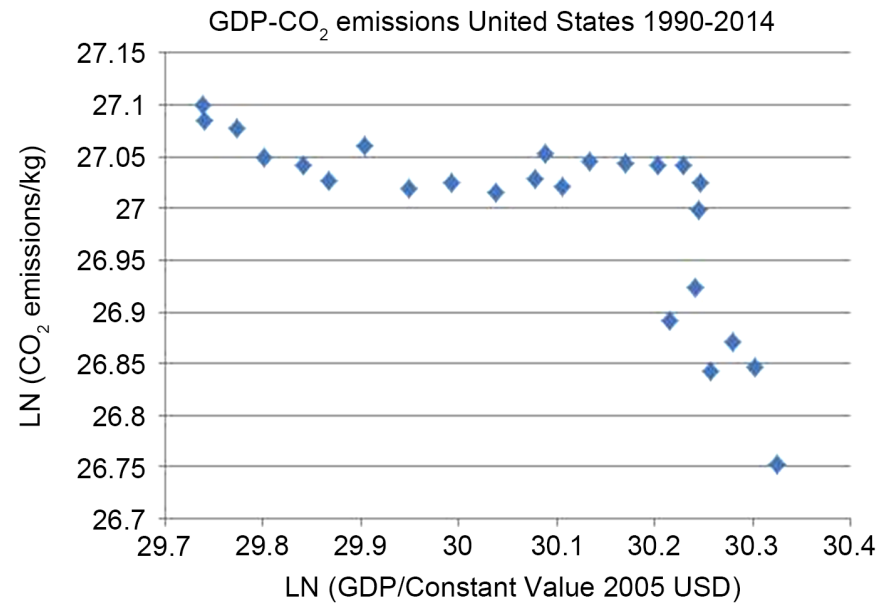

Figure 22. The US: $\mathrm{y}=-0.32 \mathrm{x}+36.7 ; \mathrm{R}^{2}=0.49$.

United States Primary Energy Consumption by Source (2015)

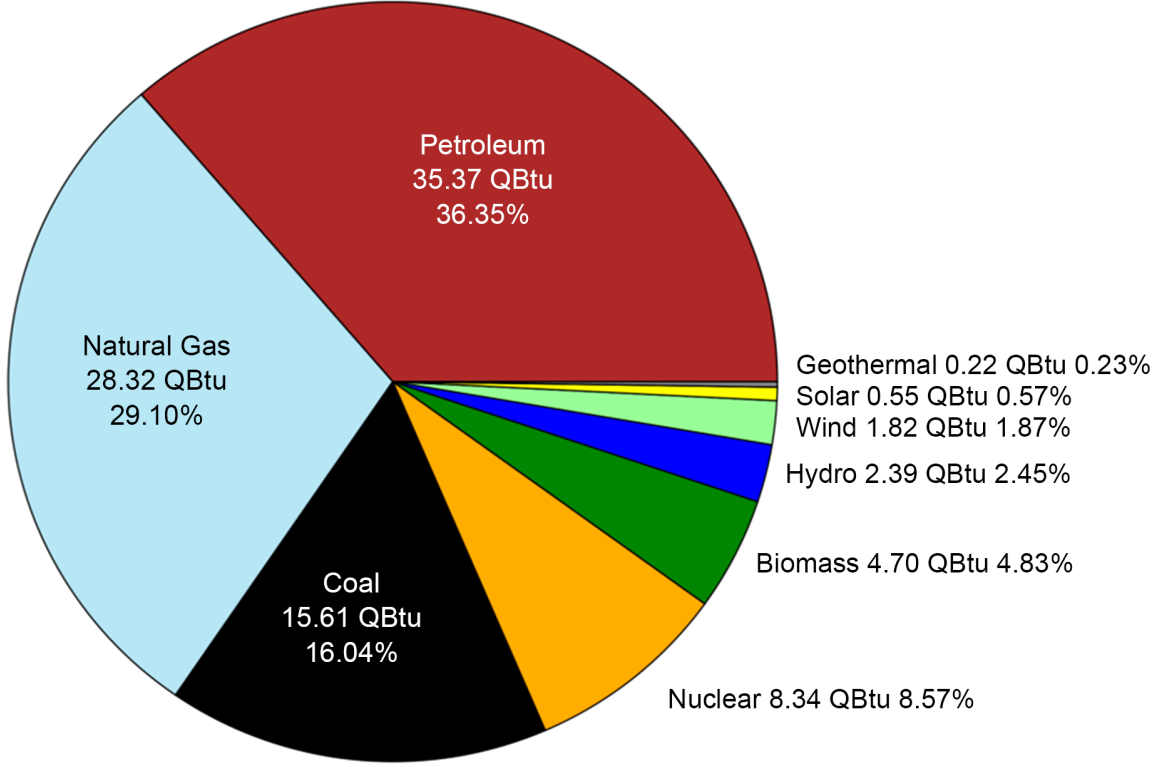

Figure 23. Energy mix in the US. 
the shale rock innovation, as more and more of energy is produced within the US, allowing even for considerable export of petroleum. The shake oil and gas revolution may though not promote decarbonisation. Further reduction of $\mathrm{CO}_{2}$ :s may meet with firm resistance from the Republican House of Congress, which may oppose the COP21 Agreement, like president elect Trump. However, solar power should be attractive in many US states, both in micro use in households and large plant use.

Not only coal consumption is being decreased but also atomic power is cut back, as it cannot compete with energy from shale rock. Yet, when solar and wind power falters, natural gas enters the picture. Solar plants take enormous amounts of space. Energy policy-making is most active in Washington, involving a complex system of tax deductions and returns.

The advent of shale oil and gas has changed the entire energy markets, lowering the price of oil most substantially. This implies not only that there will be no Hubbert peak oil for the world, but also that switching to renewable energy source will be extremely expensive, relatively speaking compared with shale oil and gas. When petroleum is abundant, then investments in carbon neutral power sources may be non-lucrative and require massive state subsidies.

Energy is extremely vital to the entire US society, including for its superpower position. When further reductions in $\mathrm{CO}_{2}$ :s threaten vital national interests, the US like other nations will no doubt employ fossil fuel, including coal. This is what the new President-elect and his administration plan at least.

\section{Japan: No Alternatives}

Japan has a huge energy consumption, but it hovers from year to year, reflecting not only the stagnation of the economy but also the occurrence of natural disasters. Japan has been forced to increase fossil fuel imports to compensate for the close down of several nuclear plants (Figure 24).

It is hardly a daring guess that the nuclear plant disaster in Japan together with the decision to close most such power plants has further increased emissions, as the country now relies upon fossil fuels much more. Governments

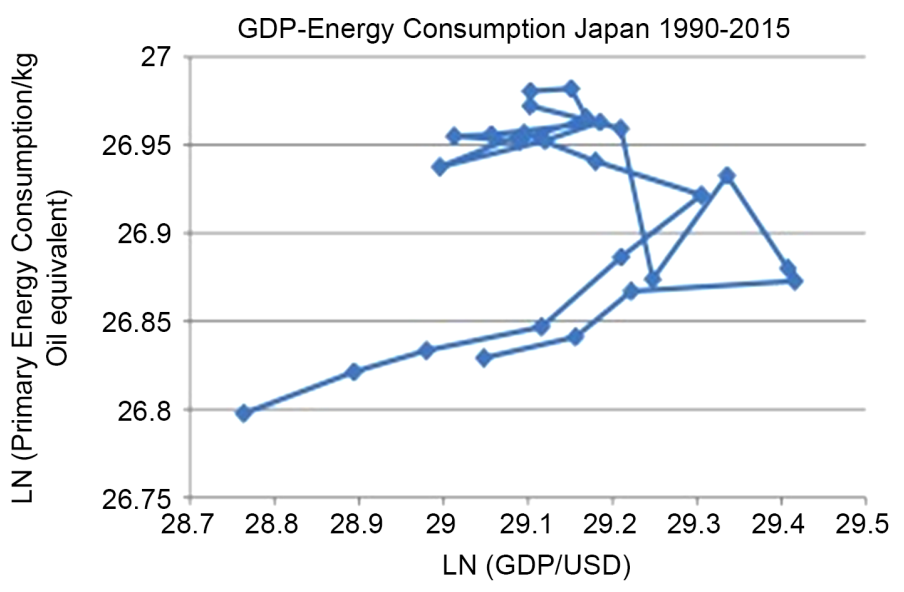

Figure 24. Japan energy and GDP: $y=0.092 x ; R^{2}=0.056$. 
make plans, but they may not hold for unforeseen developments. Japan is today more dependent upon fossil fuels than earlier due to the debacle with its nuclear energy program. Is really solar, wind or atomic power realistic in Japan on the scale needed for massive decarbonisation? When forced, governments renege, i.e. they will turn back to the fossil fuels, as for them economic growth trumps the environment. After all, nations are brutally egoistic, at least according to standard teachings in international relations (Figure 25).

With an extremely high standard of living, based on the consumption of very much electricity, Japan will have to increase its energy use. And it cannot rely upon domestic sources or renewables. Figure 26 rightly projects increased use of fossil fuels in Japan, which goes against the COP21 goals.

\section{Egypt: No Money}

If India will become the largest $\mathrm{CO}_{2}$ polluter in need of outside help, then Egypt is in the same predicament, as it is basically bankrupt. Having a quickly growing population concentrated to the Nile delta, the country faces great environmental challenges. The regime is hardly stable politically, and it receives American economic support.

If India will become the largest $\mathrm{CO}_{2}$ polluter in need of outside help, then Egypt is in the same predicament, as it is basically bankrupt. Having a quickly growing population concentrated to the Nile delta, the country faces great environmental challenges. The regime is hardly stable politically, and it receives American economic support.

As Egypt relies upon fossil fuels, especially its huge natural gas deposits, it has massive $\mathrm{CO}_{2}$ emissions, the trend of which follows its GDP (Figure 27).

It will be very difficult for Egypt to make the COP21 transformation, at least without massive external support. But where to build huge solar power plants in a country with terrorism, threat or actual?

Egypt has been lucky recently, finding large gas deposits. They are enough for strong exports. Egypt also has oil, but not enough to cover domestic consumption. Egypt is a fossil fule dependent country-more than 90 per cent, as hydro

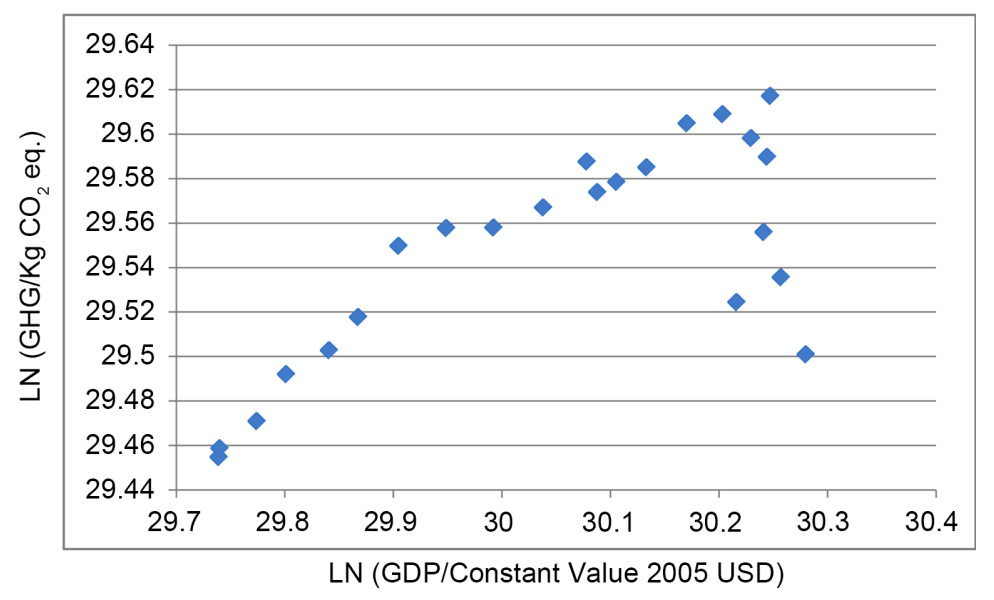

Figure 25. Japan's GDP-CO link: $\mathrm{y}=0.2648 \mathrm{x} ; \mathrm{R}^{2}=0.194$. 


\section{After Disaster}

Japan's electricity generation by source, 2010 vs. 2015 before and after the 2011 Fukushima nuclear-power disaster.

Natural gas and coal-almost all imported-and reduced consumption have made up for most of the loss of nuclear, while hydro and other renewables have shown smaller gains.

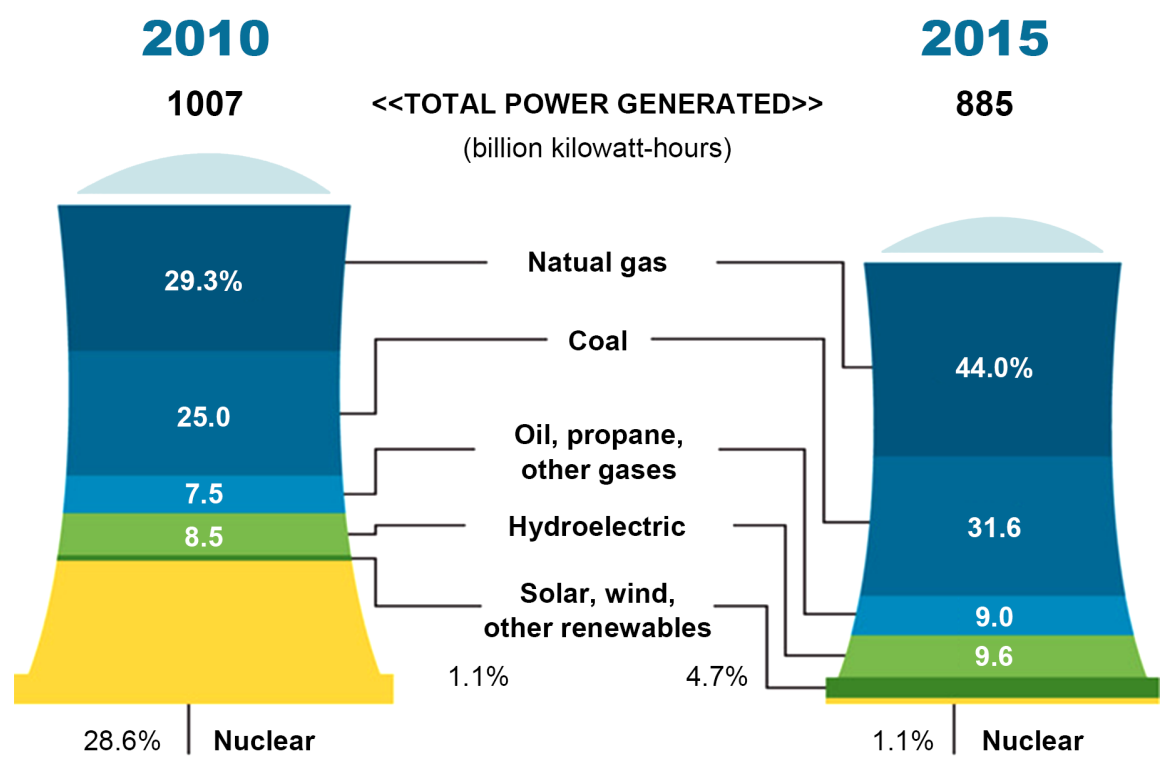

Source: Federation of Electric Power Companies of Japan THE WALL STREER JOURNAL.

Figure 26. Energy min in Japan.

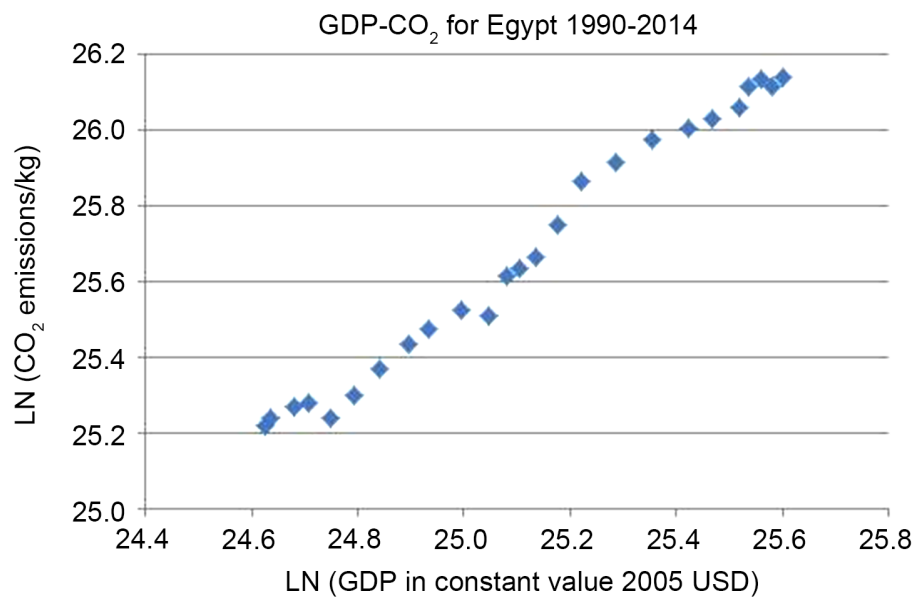

Figure 27. GDP-CO $\mathrm{CO}_{2}$ for Egypt: $\mathrm{y}=1.02 \mathrm{x} ; \mathrm{R}^{2}=0.99$.

power is not as available as one may have thought. Given the population explosion in the Nile delta, energy consumption is of course up (Figure 28).

Egypt's population is growing so fast that the country needs more energy. It can only come from its huge natural gas reserves, because oil is slowly running out. As Figure 29 shows, Egypt experiments with wind energy, but the scale of the project is too small for implementing the COP21. 


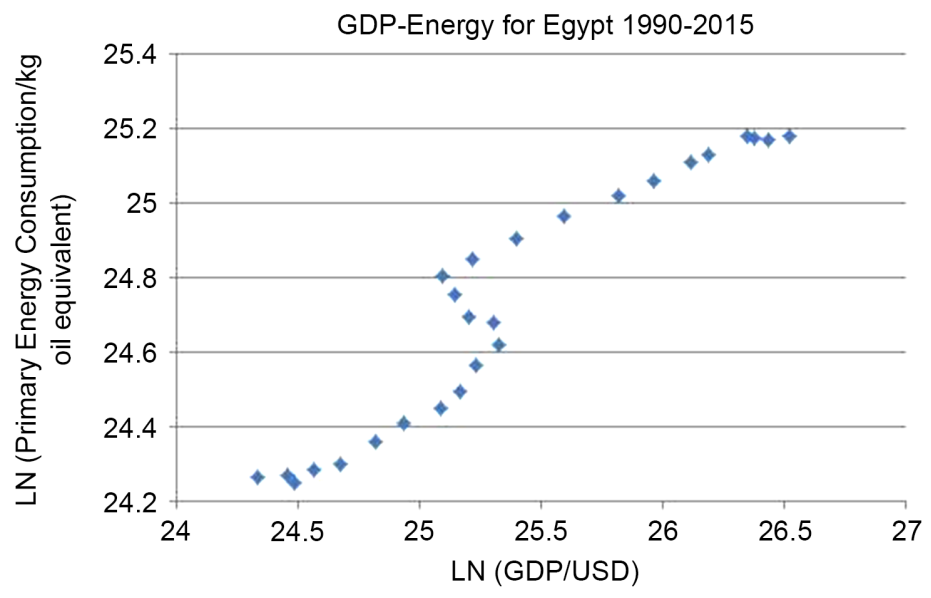

Figure 28. GDP-energy in Egypt: $y=0.49 x ; R^{2}=0.91$.

\section{Egypt's Energy Mix}

Total installed capacity of 27,000 MW as of June 2012

- Largest wind generation capacity installed in Africa and the Middle East with a total of $547 \mathrm{MW}$

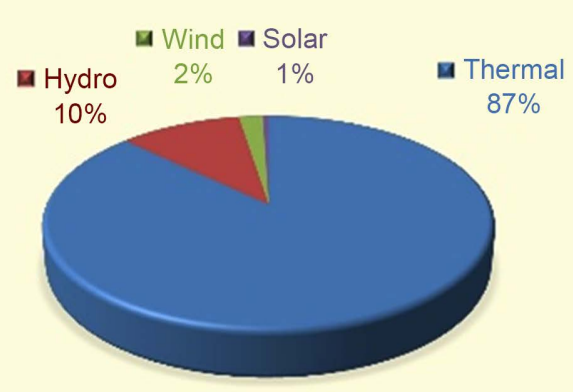

Source: Egyption Electricity Holding Company Annual Report 2011/2012

Figure 29. Energy mix in Egypt.

\section{Turkey: After "Take Off"}

Turkey has become a heavy-weight in the Asia Minor thanks to a rapid economic development of the country with huge population. Figure 30 supports this picture of Turkey as no longer a poor developing country. Comparing the picture for Turkey with that of "catch-up" nations, one may state that Turkey has the typical GDP-GHG link, despite lots of hydro power. Strong economic development is combined with heavy emissions increase. Since the world organisations - the UN, WB and IMF-opt for more of economic growth, one must ask whether emissions growth really can be halted.

Thus, Turkey has become a heavy-weight in the Asia Minor thanks to a rapid economic development of the country with huge population. Figure 31 supports this picture of Turkey as no longer a developing country. 


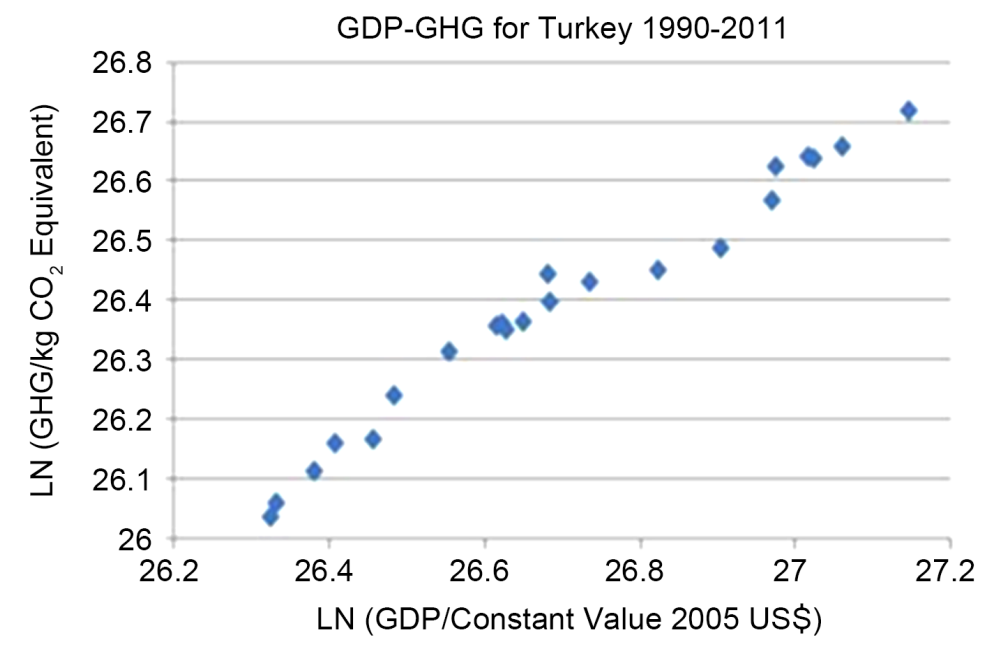

Figure 30. Turkey (equation: $\mathrm{Y}=0.7837 \mathrm{x} ; \mathrm{R}^{2}=0.972$ ).

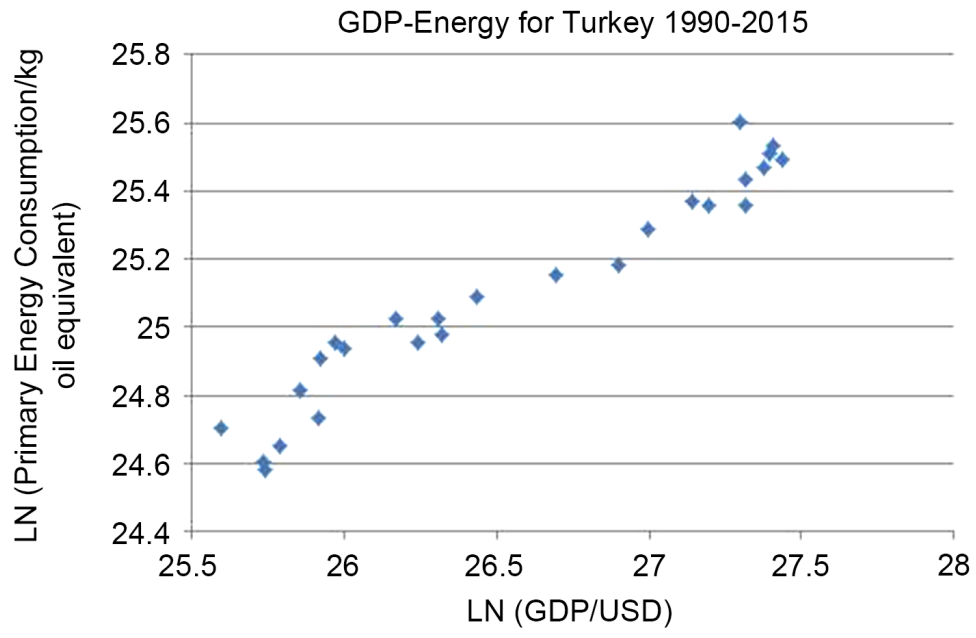

Figure 31. Turkey: energy-GDP link.

Comparing the picture for Turkey with that of France and Germany, one may state that Turkey has the most typical curves. Strong economic development is combined with heavy emissions increase. Since the world organisations-the $\mathrm{UN}, \mathrm{WB}$ and IMF-opt for more of economic growth, one must ask whether emissions growth really can be halted (Figure 32).

Turkey, aiming at a major political and economic role in relation to both the EU and the huge Turkistan, is in a process of rapid economic expansion with huge energy needs. As it relies to almost 90 per cent on fossil fuels, it will have to start a major energy transformation in order to comply with the COP21 goals. It will be difficult, especially now when Turkey is not politicallystable. Its renewables are too small simply.

The above countries are responsible for a huge part of the $\mathrm{CO}_{2}$ emissions. As they pursue the "catch-up" strategy in relation to the advanced capitalist countries, they are not very eagre to take on the burden for global decarbonisation, especially if it hurts economic development. They would demand compensation from the promised Super Fund. 


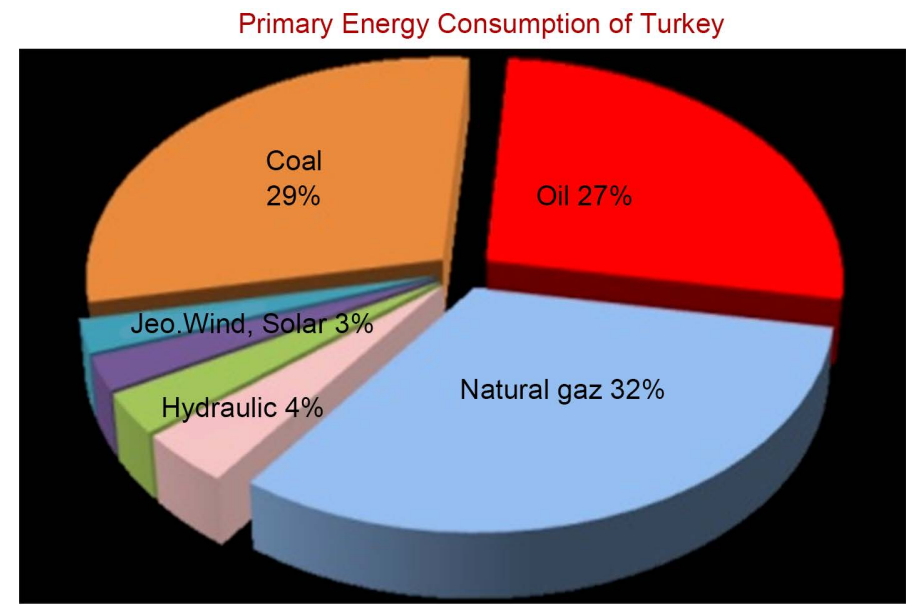

http://www.slideshare.net/omerfarukgurses/world-energy-outlook-2015presentation

Figure 32. Turkey'senergy mix. Turkey, aiming at a major political and economic role in relation to both the EU and the huge Turkistan, is in a process of rapid economic expansion with huge energy needs. As it relies to almost 90 per cent on fossil fuels, it will have to start a major energy transformation in order to comply with the COP2 1 goals. It will be difficult, especially now when Turkey is not politicallystable. Its renewables are too small simply.

\section{The Methane Threat}

Methane is now the new majorwarning. It is a potent greenhouse gas that, pound for pound, traps more than 80 times as much heat in our atmosphere than carbon dioxide. Sudden and strong increases in this greenhouse gas have been reported, with fear of methane emissions coming from the permafrost.

In addition to methane, oil and gas operations release volatile organic compounds (VOCs) into the air which contribute to coughing, wheezing, asthma attacks, and cancer. Because carbon dioxide persists so long in the atmosphere, the level of atmospheric $\mathrm{CO}_{2}$ will affect the Earth's climate for centuries, if not longer. By contrast, the level of atmospheric methane affects today's climate, but it does not last nearly as long. So methane is mainly important for controlling the peak temperature that global warming ultimately reaches. If we want to keep global warming close to 2 degrees Celsius, the globally agreed-upon climate goal, methane concentrations must go down. And because methane has so many sources, it is difficult to control.

The oil and gas industry leaks millions of tons of methane pollution and toxic chemicals into the air that harm peoples' health and speed up climate change. These industrial leaks are like an invisible oil spill happening every day. Oil and gas companies can use infrared cameras to track methane leaks and plug themor capture excess methane. Obama has told oil and gas companies to plug leaks from oil and gas wells, though these rules may get overturned by Trump. In agriculture with cows, scientists are experimenting with ways to get cows to burp less. Researchers have fed cattle things like infused flaxseed, decreasing methane emissions with 30 percent. Crop scientists are developing new genetically engineered rice varieties not transfering as much methane from flooded paddies into 
the atmosphere.

Both gases are important in different ways, but zeroing out $\mathrm{CO}_{2}$-and finding alternatives to the fossil fuels that dominate our energy system-remains the primary task. Scientists agree though that carbon-dioxide is the primary greenhouse gas we should focus upon for global warming.

\section{Conclusions}

Some of the above countries are responsible for a huge part of the $\mathrm{CO}_{2}$ emissions. As they pursue their "catch-up" strategy in relation to the advanced capitalist countries, they are not very eager to take on the burden for global decarbonisation, especially if it hurts economic development. They would demand compensation from the promised Super Fund.

The basic reason that the COP21 Agreement is not enough is that it lacks entirely the implementation stage of policy-making. Country governments sign this agreement, but action is mission. Instead, most governments plan for more of energy in the near future. Can renewable deliver this extra energy and at the same time replace coal or oil and natural gas or wood coal? No. The logic of state coordination involves the strategy of reneging. Externalities like global warming are extremely difficult to handle by international governance or treaties. Economic growth trumps environmentalism in several "catch-up" countries [14] [15]. Perhaps the UNFCCC would have to come up with a world plan to eliminate the burning of stone coal, to replace wood coal with natural gas, to face out the SUVs, the diesel trucks and buses, as well as protect every kilometer of the forests, especially the rain forests. Both air and sea transportation pollute too much. The Super Fund must quickly be put in place to evaluate and finance modern renewable energy and atomic power projects in poor and emerging economies.

\section{References}

[1] Stern, N. (2016) Why Are We Waiting? The Logic, Urgency, and Promise of Tackling Climate Change. MIT Press, Cambridge.

[2] Barro, R.J. (1991) Economic Growth in a Cross Section of Countries. The Quarterly Journal of Economics, 106, 407-443. https://doi.org/10.2307/2937943

[3] Barro, R.J. and Sala-i-Martin, X. (1992) Convergence. Journal of Political Economy, 100, 223-251. https://doi.org/10.1086/261816

[4] Barro, R.J. and Sala-i-Martin, X. (1995) Economic Growth. McGraw Hill, New York.

[5] Stern, N. (2007) The Economics of Climate Change. Cambridge University Press, Cambridge. https://doi.org/10.1017/CBO9780511817434

[6] Sachs, J.D. (2015) The Age of Sustainable Development. Columbia University Press, New York. https://doi.org/10.7312/sach17314

[7] Kaya, Y. and Yokoburi, K. (1997) Environment, Energy, and Economy: Strategies for Sustainability. United Nations University Press, Tokyo.

[8] Sachs, J. (2015) Sustainable Development for Humanity's Future. http://jeffsachs.org/2015/08/sustainable-development-for-humanitys-future/ 
[9] Sachs, J. (2012) Vol. 379. www.thelancet.com

[10] Stern, N. (2016) What Are We Waiting for? MIT Press, Cambridge.

[11] Ramesh, J. (2015) Green Signals. Oxford University Press, Oxford. https://doi.org/10.1093/acprof:oso/9780199457526.001.0001

[12] Rostow, W.W. (1960) The Stages of Economic Growth: A Non-Communist Manifesto. Cambridge University Press, Cambridge.

[13] Hayek, F. (1991) Fatal Conceit. The Errors of Socialism. University of Chicago Press, Chicago.

[14] De Bruyn, S.M. (2012) Economic Growth and the Environment: An Empirical Analysis. Springer, Berlin.

[15] Eriksson, C. (2013) Economic Growth and the Environment: An Introduction to the Theory. OUP, Oxford.

https://doi.org/10.1093/acprof:osobl/9780199663897.001.0001 


\section{Appendix 1}

The best model of carbon emissions to this day is the so-called Kaya model. It reads as follows in its standard equation version-Kaya's identity.

(E1) Kaya's identity projects future carbon emissions on changes in Population (in billions), economic activity as GDP per capita (in thousands of $\$ U S$ (1990)/person year), energy intensity in Watt years/dollar, and carbon intensity of energy as Gton $\mathrm{C}$ as $\mathrm{CO}_{2}$ per TeraWatt year."

(http://climatemodels.uchicago.edu/kaya/kaya.doc.html)

Concerning the equation (E1), it may seem premature to speak of a law or identity that explains carbon emissions completely, as if the Kaya identity is a deterministic natural law. It will not explain all the variation, as there is bound to be other factors that impact, at least to some extent. Thus, it is more proper to formulate it as a stochastic law-like proposition, where coefficients will be estimate using various data sets, without any assumption about stable universal parameters. Thus, we have this equation format for the Kaya probabilistic law-like proposition, as follows:

(E2) Multiple Regression: $Y=a+b_{1} X_{1}+b_{2} X_{2}+b_{3} X_{3}+\cdots+b_{t} X_{t}+u$

Note: $\mathrm{Y}=$ the variable that you are trying to predict (dependent variable); $\mathrm{X}=$ the variable that you are using to predict $Y$ (independent variable); $a=$ the intercept; $\mathrm{b}=$ the slope; $\mathrm{u}=$ the regression residual. Note:

http:www.investopedia.com/terms/r/regression.asp\#ixzz4Mg4Eyugw

Thus, using the Kaya model for empirical research on global warming, the following anthropogenic conditions would affect positively carbon emissions:

(E3) $\mathrm{CO}_{2}: \mathrm{s}=\mathrm{F}(\mathrm{GDP} /$ capita, Population, Energy intensity, Carbon intensity), in a stochastic form with a residual variance, all to be estimated on most recently available data from some 59 countries. I make two empirical estimations of this probabilistic Kaya model, one longitudinal for 1990-2014 as well as one crosssectional for 2014.I make an empirical estimation of this probabilistic Kaya model-the longitudinal test for 1990-2014, World data 1990-2015:

(E4) $\operatorname{Ln} \mathrm{CO}_{2}=0.62^{\star} \mathrm{LN}$ Population $+1.28^{\star} \mathrm{LN}$ (GDP/Capita) $+0.96^{\star} \mathrm{LN}$ (Energy/GDP); R2 $=0.90$.

In a stochastic form with a residual variance, all to be estimated on data from some 59 countries, I make an empirical estimation of this probabilistic Kaya model-the cross-sectional test for 2014:

(E5) $\mathrm{k} 1=0.68, \mathrm{k} 2=0.85, \mathrm{k} 3=0.95, \mathrm{k} 4=0.25 ; \mathrm{R} 2=0.80$.

Note: $\mathrm{LN} \mathrm{CO}_{2}=\mathrm{k} 1^{*} \mathrm{LN}(\mathrm{GDP} / \mathrm{Capita})+\mathrm{k} 2^{*}$ (dummy for Energy Intensity) + k3* (LNPopulation) $+\mathrm{k} 4^{\star}$ (dummy for Fossil Fuels/all) Dummy for fossils 1 if more than $80 \%$ fossil fuels; $\mathrm{k} 4$ not significantly proven to be non-zero, all others are. $(\mathrm{N}=59)$.

These two tests of the Kaya model shows that the key factors in anthropogenic climate change are the size of the economy, energy consumption and the carbon content of energy. 


\section{Appendix 2. Energy Source and $\mathrm{CO}_{2}$}

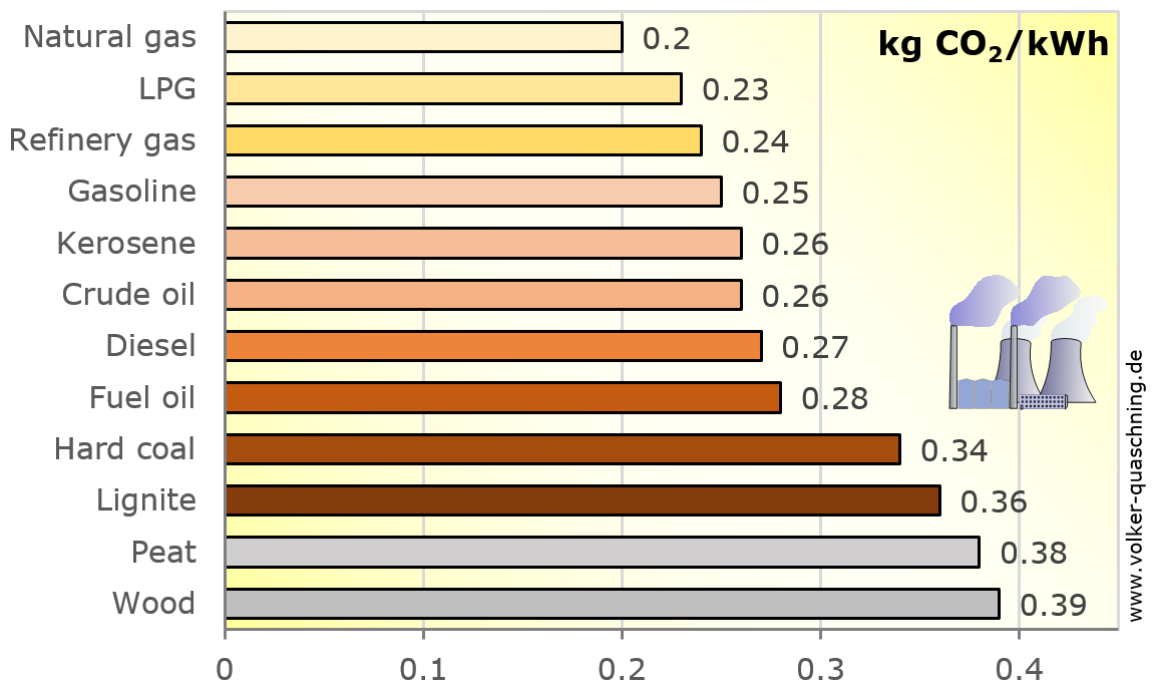

\section{GDP Sources}

World Bank national accounts data, data.worldbank.org

OECD National Accounts data files

\section{GHG and Energy Sources}

World Resources Institute CAIT Climate Data Explorer, cait.wri.org

EU Joint Research Centre Emission Database for Global Atmospheric

Research http://edgar.jrc.ec.europa.eu/overview.php

UN Framework Convention on Climate Change

http://unfccc.int/ghg_data/ghg_data_unfccc/time_series_annex_i/items/3814.php International Energy Agency. Paris.

Energy Information Administration. Washington, DC.

BP Energy Outlook 2016.

EU Emissions Database for Global Research EDGAR,

http://edgar.jrc.ec.europa.eu/

World Bank Data Indicators, data.worldbank.org

British Petroleum Statistical Review of World Energy 2016 Literature 
Submit or recommend next manuscript to OALib Journal and we will provide best service for you:

- Publication frequency: Monthly

- 9 subject areas of science, technology and medicine

- Fair and rigorous peer-review system

- Fast publication process

- Article promotion in various social networking sites (LinkedIn, Facebook, Twitter, etc.)

- Maximum dissemination of your research work

Submit Your Paper Online: Click Here to Submit

Or Contact service@oalib.com 